\title{
Produksi dan Pemurnian Xilooligosakarida dari Xilan Tongkol Jagung menggunakan Xilanase Streptomyces P26B4 dan Khamir IP4
}

\section{(Production and Purification of Xylooligosaccharides from Corncobs Xylan using Streptomyces P26B4 Xylanase and Yeast IP4)}

\author{
Andika Susantri ${ }^{1}$, Titi Candra Sunarti ${ }^{2}$, Anja Meryandini $i^{3,4 *}$ \\ (Diterima Oktober 2020/Disetujui April 2021)
}

\begin{abstract}
ABSTRAK
Xilooligosakarida (XOS) merupakan oligomer gula dari xilan yang dapat dijadikan sebagai prebiotik untuk meningkatkan kesehatan saluran pencernaan. XOS dapat dihasilkan dari tongkol jagung yang merupakan produk samping pertanian. Tujuan dari penelitian ini adalah untuk menghasilkan XOS melalui hidrolisis xilan tongkol jagung menggunakan xilanase Streptomyces P26B4. Produk hidrolisis juga terdiri atas monomer xilosa; oleh karena itu xilooligosakarida dimurnikan dengan menggunakan khamir IP4. Produk hidrolisis xilan dianalisis secara kuantitatif berdasarkan nilai gula pereduksi dan derajat polimerisasi (DP), diperkuat secara kualitatif dengan TLC. Komponen gula dianalisis setelah penambahan khamir oleh HPLC. Isolat xilanase P26B4 memiliki aktivitas tertinggi pada inkubasi hari ke $7, \mathrm{pH}$ bufer sitrat 5,5 dan suhu $50^{\circ} \mathrm{C}$. Nilai DP terendah dari hidrolisis xilan adalah 2,49 pada konsentrasi $6 \%$, dan 24 jam inkubasi. Kromatogram TLC menunjukkan bahwa produk xilosa dan XOS dihasilkan. Pemurnian XOS pada konsentrasi substrat $6 \%$ menunjukkan penurunan luas areal xilosa sebelum dan setelah penambahan khamir masing-masing 1,87\% dan 1,41\%. Oleh karena itu, khamir IP4 memiliki potensi untuk mengkonsumsi xilosa dan memurnikan XOS.
\end{abstract}

Kata kunci: khamir IP4, pemurnian, xilan tongkol jagung, xilanase Streptomyces P26B4, xilooligosakarida

\section{ABSTRACT}

Xylooligosaccharides (XOS) are sugar oligomers from xylan that can be used as prebiotics to improve digestive tract health. Xylan can be extracted from corncobs which are a by-product of agriculture. The purpose of this study was to produce XOS through hydrolysis of corn cobs xylan using Streptomyces P26B4 xylanase. The products of hydrolysis also consisted of monomer xylose; for that xilooligosaccharides were purified using yeast IP4. The xylan hydrolysis products are quantitatively analyzed based on the value of reducing sugars and degree of polymerization (DP), strengthened qualitatively with TLC. Sugar component was analyzed after the addition of yeast by HPLC. P26B4 xylanase isolates had the highest activity on the 7th day incubation, $\mathrm{pH} 5,5$ buffer citrate and temperature of $50^{\circ} \mathrm{C}$. The lowest DP value of xylan hydrolysis was 2.49 at a concentration of $6 \%$, and the 24th hour of incubation. TLC chromatograms showed that xylose and XOS products were produced. Purification of XOS at $6 \%$, showed a decreasing in the area of xylose before and after receiving yeast respectively $1.87 \%$ and $1.41 \%$.Therefore, yeast IP4 has the potential to consume xylose amnd purify the XOS.

Keywords: corncobs xylan, IP4 yeast, purification, Streptomyces P26B4 xylanase, xylooligosaccharides

\section{PENDAHULUAN}

Xilooligosakarida (XOS) merupakan oligomer gula tersusun dari unit xilosa yang dihubungkan oleh ikatan

1 Sekolah Pascasarjana, Program Studi Bioteknologi, Kampus Darmaga IPB, Institut Pertanian Bogor, Bogor 16680

2 Departemen Teknologi Industri Pertanian, Fakultas Teknologi Pertanian, Kampus Darmaga IPB, Institut Pertanian Bogor, Bogor 16680

3 Departemen Biologi, Fakultas Matematika dan IImu Pengetahuan Alam, Institut Pertanian Bogor, Kampus Darmaga IPB, Bogor 16680

4 Pusat Penelitian Sumberdaya Hayati \& Bioteknologi (PPSHB)-LPPM IPB, Kampus IPB Darmaga, Institut Pertanian Bogor, Bogor 16680

* Penulis Korespondensi:

Email: ameryandini@apps.ipb.ac.id $\beta-1 \rightarrow 4$ xilosidik dengan rumus molekul $\mathrm{C}_{5 n} \mathrm{H}_{8 \mathrm{n}+2} \mathrm{O}_{4 n+1}$ dan memiliki derajat polimerisasi (DP) $\leq 20$ yaitu xilobiosa (X2), xilotriosa (X3), xilotetrosa (X4), xilopentosa (X5), xilohexosa (X6) dan seterusnya (Samanta et al. 2015a). Xilooligosakarida yang memiliki DP 2-5 dapat dijadikan sebagai prebiotik (Singh et al. 2015). Prebiotik dapat didefinisikan sebagai makanan yang tidak dapat dicerna oleh saluran pencernaan tetapi dapat memengaruhi inang dengan merangsang pertumbuhan sejumlah bakteri baik di dalam usus untuk meningkatkan kesehatan inang (Rastall \& Gibson 2015). Chapla et al. (2012) mengevaluasi kemampuan galur yang diketahui sebagai probiotik yaitu Bifidobacterium adolescentis, Bifidobacterium bifidum, Lactobacillus fermentum, Lactobacillus acidophilus menggunakan XOS. XOS tersebut mampu difermentasi dengan baik oleh 
mikroorganisme usus yang menguntungkan secara in vitro sehingga dapat dijadikan sebagai prebiotik yang ideal. XOS secara alami dapat ditemukan pada beberapa makanan, seperti buah, sayuran, madu, susu atau pada tanaman yang banyak mengandung xilan seperti ampas tebu, bambu, tongkol jagung, dedak gandum, jerami padi dan tangkai kapas (Mano et al. 2018).

Tongkol jagung merupakan salah satu hasil samping pertanian yang melimpah karena pemanfaatan jagung yang terus meningkat seperti digunakan sebagai bahan baku produk industri, dikonsumsi manusia dan sebagai bahan pakan ternak, sehingga menghasilkan sejumlah produk samping. Berdasarkan data Kementerian Pertanian tahun 2019 produksi jagung Indonesia sebesar 33 juta ton, sehingga jumlah tongkol jagungnyapun berlimpah. Tongkol jagung dapat digunakan sebagai sumber XOS karena mengandung bahan lignoselulosa yang terdiri atas selulosa $38,8 \%$, hemiselulosa $44,4 \%$ dan lignin $11,9 \%$ (Pointner et al. 2014). Chapla et al. (2012) memproduksi XOS dari tongkol jagung secara enzimatis dengan hasil sebanyak $6,83 \mathrm{mg} / \mathrm{mL}$.

Komponen utama dari hemiselulosa adalah xilan, yang dapat dihidrolisis secara enzimatik oleh enzim xilanase. Produksi enzim xilanase dapat dihasil-kan dari berbagai mikroorganisme seperti bakteri dan jamur. Enzim dari Streptomyces lebih menarik dibandingkan enzim yang berasal dari sumber lain karena aktivitas yang tinggi. Selain itu genus Streptomyces memiliki miselium semu yang dapat menembus ke dalam substrat dan menghasilkan enzim hidrolitik ekstraseluler yang mampu mendegradasi biomassa lignoselulosa (Prakash et al. 2013; Dilip et al. 2013). Xilanase Streptomyces telah dilaporkan sebelumnya, seperti Streptomyces violascences BF3.10 (Salupi et al. 2015), Streptomyces megasporus DSM 41476 (Qiu et al. 2010). Xilanase dapat diklasifikasikan berdasarkan substrat yang dihidrolisis, yaitu $\beta$-xilosidase, eksoxilanase, dan endoxilanase menjadi xilosa dan XOS (Collins et al. 2005). XOS dengan kualitas yang baik harus dimurnikan dengan menghilangkan senyawa monosakarida yaitu xilosa sehingga diperoleh XOS dengan kemurnian tinggi. Beberapa metode yang digunakan untuk pemurnian XOS yaitu teknik pemisahan kromatografi (Moniz et al. 2014), teknologi membran (Parajo 2013), adsorpsi (Zhao et al. 2012). Metode alternatif lain untuk meningkatkan kemurnian produksi XOS yaitu menggunakan mikroorganisme yang memiliki kemampuan dalam menggunakan xilosa sebagai sumber karbon. Salah satu jenis mikroorganisme tersebut adalah khamir. Sangwan et al. (2014) telah menggunakan khamir untuk menurunkan kadar galaktosa pada produksi galaktooligosakarida (GOS).

Pada penelitian ini digunakan khamir IP4 (Pichia kudriavzevii) yang diperoleh dari penelitian sebelumnya dan berasal dari fermentasi kakao. Khamir ini dapat menggunakan gula xilosa sebagai sumber karbon (Inderiani 2017). Berdasarkan data tersebut, maka penelitian ini bertujuan untuk memproduksi XOS dari xilan tongkol jagung menggunakan xilanase Streptomyces dan pemurnian xilooligosakarida melalui penambahan khamir.

\section{METODE PENELITIAN}

\section{Tempat dan Waktu Penelitian}

Penelitian ini dimulai pada bulan Oktober 2018September 2019. Lokasi Penelitian bertempat di Pusat Penelitian Sumberdaya Hayati dan Bioteknologi (PPSHB), Institut Pertanian Bogor (IPB) dan Laboratorium Pusat Studi Biofarmaka Tropik LPPM IPB, Bogor, Jawa Barat.

\section{Bahan}

Bahan yang digunakan dalam penelitian ini adalah tongkol jagung asal Kebun Percobaan Leuwikopo IPB (Bogor), Isolat Streptomyces P26B4 dan Isolat khamir Pichia kudriavzevii IP4 yang merupakan koleksi dari Laboratorium PPSHB IPB, xilan Beechwood 0,5\%, media ISP4 (Soluble starch $1 \mathrm{~g}$, K2HPO4 0,1 g, $\mathrm{MgSO} 4 \cdot 7 \mathrm{H} 2 \mathrm{O} 0,1 \mathrm{~g}, \mathrm{NaCl} 0,1 \mathrm{~g}, \mathrm{CaCO} 30,2 \mathrm{~g}$, (NH4)2•SO4 0,4 g, Agar $2 \mathrm{~g}$, Trace salt solution 0,1 mL) dalam $100 \mathrm{~mL}$ air, media YPG (Yeast peptone glucose).

\section{Penyiapan Xilan Tongkol Jagung}

Bahan baku tongkol jagung dikeringkan kemudian digiling dengan hammer mill hingga berukuran 40 mesh. Tongkol jagung sebanyak $500 \mathrm{~g}$ direndam di dalam larutan $\mathrm{NaOCl} 0,5 \%$ selama 5 jam (Proses delignifikasi), Setelah 5 jam sampel dibilas dengan air dan disaring, kemudian endapan dikeringkan pada suhu $35^{\circ} \mathrm{C}$ selama 24 jam. Selanjutnya padatan direndam dalam larutan $\mathrm{NaOH} 10 \%$ selama 24 jam pada suhu $28^{\circ} \mathrm{C}$ (Proses ekstraksi). Setelah 24 jam, disentrifugasi selama 30 menit dengan kecepatan $4000 \mathrm{rpm}$. Filtrat yang dihasilkan ditampung untuk diukur pH-nya, kemudian dinetralkan dengan menggunakan $\mathrm{HCl} 6 \mathrm{~N}$, selanjutnya disentrifugasi selama 30 menit dengan kecepatan putaran 4000 rpm. Supernatan yang dihasilkan dari sentrifugasi mengandung xilan. Xilan yang larut dalam air dipisahkan dengan menambahkan etanol 95\%. Perbandingan supernatanetanol adalah 1:3, kemudian disentrifugasi kembali dengan kecepatan $4000 \mathrm{rpm}$ selama 30 menit. Endapan yang dihasilkan merupakan xilan. Xilan dikeringkan kemudian dihaluskan sehingga diperoleh bubuk xilan ukuran 80 mesh.

\section{Aktivitas Enzim Xilanase}

Isolat P26B4 diremajakan pada media ISP4 kemudian diinkubasi selama 72 jam pada suhu ruangdan diamati pertumbuhan koloninya. Aktivitas enzim xilanase isolat dilakukan secara kualitatif dan kuantitatif. Isolat diremajakan pada media ISP4 kemudian diinkubasi selama 72 jam pada suhu ruang. Selanjutnya isolat ditumbuhkan pada cawan agar 
mengandung xilan tongkol jagung 0,5\% (Komposisi g/100 mL 0,5 Xilan tongkol jagung, 0,2 Ekstrak khamir, $0,02 \mathrm{MgSO}_{4} \cdot 7 \mathrm{H}_{2} \mathrm{O}, 0,05 \mathrm{~K}_{2} \mathrm{HPO}_{4}, 0,075 \mathrm{KNO}_{3}, 0,002$ $\mathrm{FeSO}_{4} \cdot 7 \mathrm{H}_{2} \mathrm{O}, 0,004 \mathrm{CaCl}_{2}, 0,1$ Glukosa) (Kholis et al. 2015)

Pertumbuhan isolat diamati setelah 72 jam dengan mengukur diameter isolat, selanjutnya dilakukan pewarnaan menggunakan merah kongo 0,1\%. Pembentukan zona bening dijadikan parameter kualitatif enzim xilanase.

Parameter kuantitatif meliputi penentuan waktu optimum produksi xilanase tertinggi, penentuan $\mathrm{pH}$ dan suhu optimum serta stabilitasnya. Penentuan waktu optimum terhadap isolat dilanjutkan dengan pembuatan kurva aktivitas enzim. Supernatan sebagai ekstrak enzim kasar (EEK) sebanyak 0,5 mL diukur aktivitasnya menggunakan substrat xilan Beechwood $0,5 \%$ dan waktu inkubasi 15 menit. Gula pereduksi yang dihasilkan diukur dengan metode DNS (Miller 1959) menggunakan spektrofotometer dengan panjang gelombang $(\lambda) 540 \mathrm{~nm}$. Satu unit $(U)$ aktivitas xilanase didefinisikan sebagai sejuml ah $\mu$ mol xilosa yang dihasilkan setiap $1 \mathrm{~mL}$ enzim dalam waktu 1 menit.

Penentuan $\mathrm{pH}$ optimum digunakan ekstrak enzim kasar (EEK) sebanyak 0,5 mL dan waktu ikubasi 15 menit, diuji menggunakan bufer $(50 \mathrm{mM})$ pada $\mathrm{pH}$ 4,5-10,0 dengan interval $\mathrm{pH} 0,5$. Kondisi $\mathrm{pH} 4,5-6,0$ digunakan larutan bufer sitrat, $\mathrm{pH}$ 6,0-8,0 digunakan larutan bufer fosfat dan $\mathrm{pH}$ 8,0-10,0 digunakan larutan bufer glisin $\mathrm{NaOH}$. Penentuan suhu optimum dilakukan pada suhu $30-90^{\circ} \mathrm{C}$ dengan interval $10^{\circ} \mathrm{C}$ menggunakan $\mathrm{pH}$ optimum. Penentuan stabilitas enzim dilakukan dengan menginkubasi enzim ekstrak kasar pada suhu $10^{\circ} \mathrm{C}$ dan $28^{\circ} \mathrm{C}$, kemudian pengukuran aktivitas enzim pada jam ke-0, ke-3, ke-24, ke-48, ke72, dan ke-96. Daya tahan enzim diketahui dengan menghitung nilai (\%) aktivitas enzim relatif (Inayah et al. 2016). Gula pereduksi yang terbentuk sebagai akibat dari aktivitas enzim diukur dengan menggunakan Metode DNS (3.5 Dinitrosalycilic acid) (Miller 1959).

\section{Produksi Xilooligosakarida Secara Enzimatis}

Sebanyak $15 \mathrm{ml}$ enzim xilanase yang diperoleh dari kultur bakteri yang berumur 7 hari digunakan untuk produksi XOS dari $100 \mathrm{~mL}$ xilan tongkol. Konsentrasi substrat terdiri atas 3\%, 6\% xilan tongkol jagung dan xilan beechwood $6 \%$ sebagai pembanding (b/v) serta diinkubasi pada (0-24 jam) pada $\mathrm{pH}$ dan suhu optimum enzim. Pengukuran produk hidrolisis dilakukan pada jam ke- 0, 6, 12, 24. Analisis produk hidrolisis secara kuantitatif berdasarkan pada nilai derajat polimerasi (DP). Derajat polimerasi dihitung berdasarkan perbandingan antara total gula (Dubois et al. 1956) dengan gula pereduksi yang dihasilkan, sedangkan secara kualitatif dimonitor pembentukan pita pada plat Kromatografi Lapis Tipis.

\section{Pemurnian Xilooligosakarida Oleh Khamir}

Isolat khamir IP4 diremajakan pada media Agar YPG (YPG, Yeast Extract-petone-Glucose Agar) hingga $\mathrm{OD}_{600} \mathrm{~nm}=0,8$, kemudian diinokulasikan ke dalam $100 \mathrm{~mL}$ media YPGB, diinkubasi selama 24 jam pada suhu ruang. Khamir IP4 ditambahkan ke dalam produk hidrolisis dengan perbandingan 1:1 (v/v), diinkubasi selama 8 jam. Selanjutnya disaring dengan filter (Millipore) 0,22 $\mu \mathrm{m}$ (Sangwan et al. 2014). Analisis komponen gula dari hasil hidrolisis dianalisis dengan HPLC (High performance liquid chromatography) Shimadzu (consumable : 2 syringeless tube GE), kolom Aminex HPX-87C, Mode Binary pump.

\section{Analisis Statistik}

Metode penelitian menggunakan Rancangan Acak Lengkap (RAL) sebanyak 3 ulangan dengan pengamatan berulang. Data yang diperoleh dianalisis dengan sidik ragam (ANOVA), bila berpengaruh nyata dilanjutkan dengan Uji Tuckey pada taraf 5\%. Data dianalisis menggunakan software SAS 3.4.

\section{HASIL DAN PEMBAHASAN}

\section{Penyiapan Xilan Tongkol Jagung}

Proses ekstraksi xilan tongkol jagung menghasilkan rendaman xilan sebesar $7.2 \%$. Penggunaan Larutan $\mathrm{NaOH}$ pada proses ekstraksi berfungsi melemahkan ikatan antara selulosa dan hemiselulosa sehingga mempermudah ekstraksi xilan tersebut (Taherzadeh dan Karimi 2007). Rendemen xilan yang dihasilkan tergantung pula sumber bahan yang digunakan. Salupi et al. (2015) melaporkan bahwa ekstraksi xilan dari tongkol jagung sebanyak $500 \mathrm{~g}$ diperoleh xilan sebesar $39,64 \mathrm{~g}(7,9 \%)$ dan Kholis et al. (2015) menghasilkan xilan sebanyak 155,34 g (15,5\%) dari ekstraksi tangkai tembakau $1 \mathrm{~kg}$. Perbedaan rendemen xilan yang dihasilkan dari ekstraksi disebabkan oleh beberapa faktor diantaranya metode ekstraksi yang digunakan, jenis varietas jagung, dan umur jagung, serta dipengaruhi oleh lingkungan (Zheng et al. 2014).

\section{Karakteristik Isolat dan Enzim Xilanase}

Karakteristik morfologi isolat P26B4 berwarna krem (putih kecoklatan), kering dan memiliki bau seperti tanah (Gambar 1a). Hasil pewarnaan dengan merah kongo memperlihatkan adanya zona bening disekitar koloni menghasilkan indeks xilanolitik 2,38 \pm 0,05 (Gambar 1b). Putri et al. (2019) dari 41 isolat aktinomisetes terdapat 10 isolat yang memiliki kemampuan dalam menghasilkan xilanase dengan nilai indeks xilanolitik tertinggi 1,07 dan 1,67 pada media yang mengandung xilan. Zona bening yang terbentuk menunjukkan bahwa isolat bakteri P26B4 mampu mendegradasi substrat xilan menjadi bentuk yang lebih sederhana. 
Isolat P26B4 memiliki aktivitas di hari ke-4 dan terus mengalami peningkatan hingga hari ke-7 (Gambar 2). Peningkatan aktivitas enzim sejalan dengan pertumbuhan biomassa sel (Salupi et al. 2015). Pada hari ke-4 hingga hari ke-7 pertumbuhan isolat berada pada fase eksponensial.

Fase eksponensial merupakan fase pertumbuhan sel yang ditandai dengan meningkatnya jumlah sel karena proses pembelahan sel terjadi secara maksimal. Aktivitas tertinggi diperoleh pada hari ke-7 sebesar $0,39 \mathrm{U} / \mathrm{mL}$, selanjutnya pada hari ke-8 hingga hari ke-15 terus mengalami penurunan aktivitas. Setelah mencapai titik optimum secara perlahan aktivitas enzim xilanase mulai menurun. Hal tersebut disebabkan adanya kematian sel karena berkurangnya nutrisi yang terdapat di dalam media yang menyebabkan tekanan fisiologis pada mikroorganisme dan penurunan aktivitas endoxilanase akibat adanya penghambatan produk akhir (Chapla et al. 2012). Hari ke-7 tersebut digunakan sebagai dasar untuk lama waktu produksi enzim xilanase selanjutnya pada media xilan tongkol jagung.

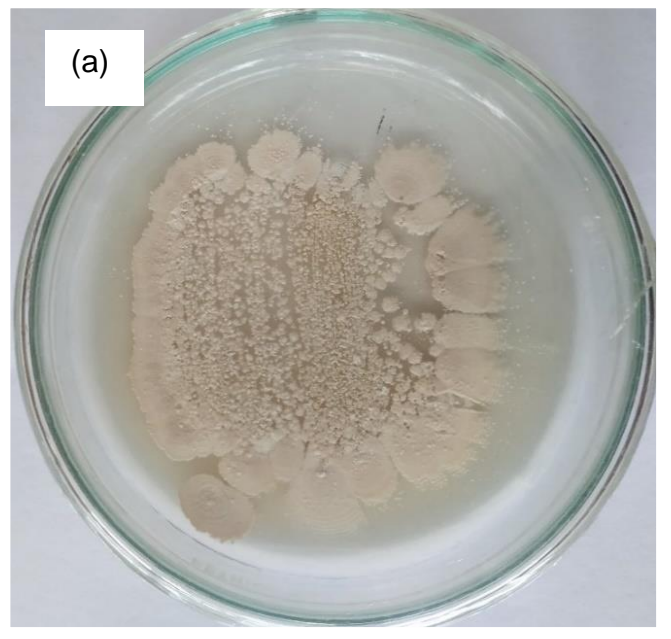

Setiap enzim memiliki pH dan suhu optimum agar dapat bekerja secara optimum. Enzim xilanase bekerja pada rentang $\mathrm{pH}$ yang luas yaitu $\mathrm{pH} 4,5-8,5$ (Gambar 3), namun xilanase dari isolat P26B4 memiliki aktivitas tertinggi pada $\mathrm{pH} 5,5$ sebesar $1,45(\mathrm{U} / \mathrm{mL})$. Bhosale et al. (2011) melaporkan isolat Streptomyces rameus menghasilkan enzim xilanase optimum pada $\mathrm{pH}$ 8,5. (Knob et al. 2013) xilanase Penicillium glabrum stabil pada rentang $\mathrm{pH} 2,5-5,0$. Isolat yang berbeda menunjukkan kondisi $\mathrm{pH}$ berbeda-beda.

Suhu merupakan salah satu parameter penting dalam kinerja enzim. Hasil uji pengaruh suhu terhadap aktivitas enzim menunjukkan terdapat dua puncak (Gambar 4). Puncak pertama memiliki aktivitas tertinggi pada suhu $50^{\circ} \mathrm{C}$ sebesar $3,29 \mathrm{U} / \mathrm{mL}$, puncak kedua pada suhu $70^{\circ} \mathrm{C}$ dengan aktivitas enzim sebesar $2,64 \mathrm{U} / \mathrm{mL}$.

Hal ini sejalan dengan penelitian yang dilakukan oleh Ting et al. (2014) yang melaporkan bahwa terdapat 2 puncak aktivitas enzim xilanase dihasilkan dari Streptomyces sp. pada suhu $40^{\circ} \mathrm{C}$ dan $60^{\circ} \mathrm{C}$. Terdapatnya 2 puncak aktivitas enzim diduga karena adanya dua jenis enzim yang berbeda yaitu endo- $\beta$ -

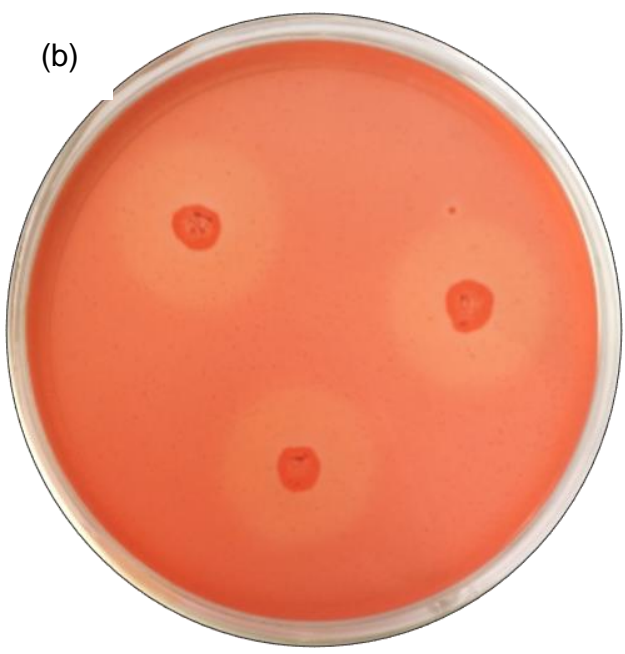

Gambar 1 Karakter isolat P26B4. (a) Morfologi koloni yang ditumbuhkan pada media ISP4 setelah inkubasi 72 jam pada suhu ruang (b) Pembentukan zona bening dari isolat P26B4 yang ditumbuhkan pada media xilan tongkol jagung 0,5\%, setelah pewarnaan menggunakan merah kongo $0,1 \%$.

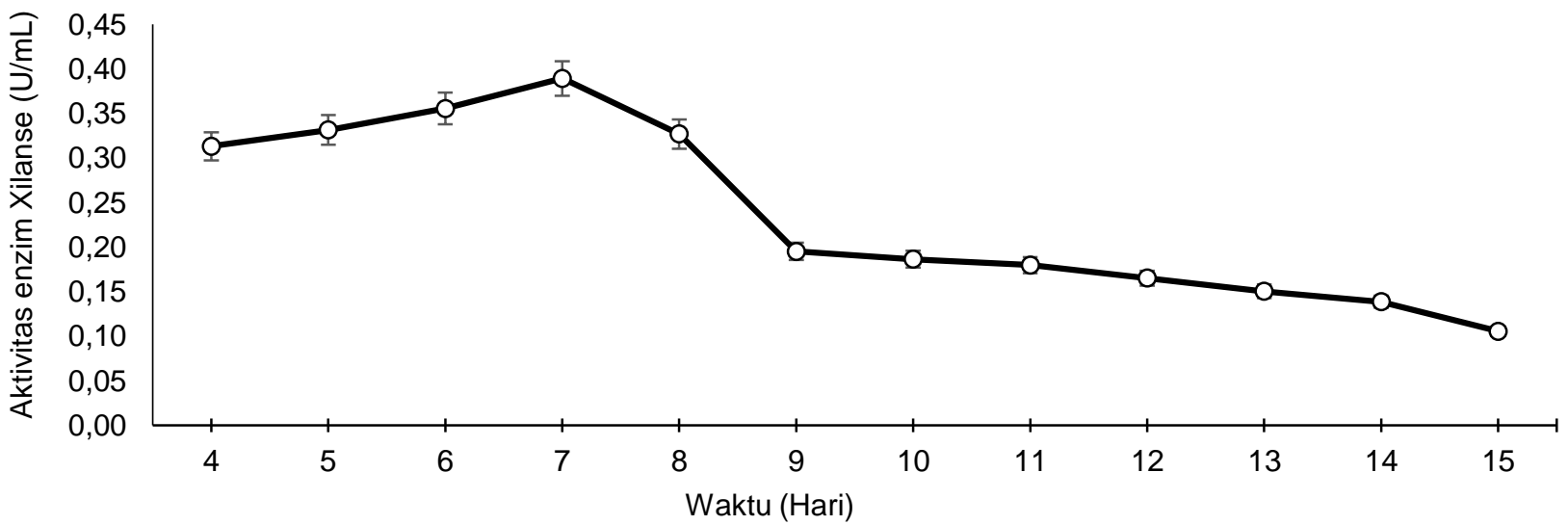

Gambar 2 Kurva aktivitas enzim xilanase isolat P26B4 pada media cair xilan tongkol jagung 0,5\%, bufer fosfat $\mathrm{pH} 7$, inkubasi suhu ruang. 


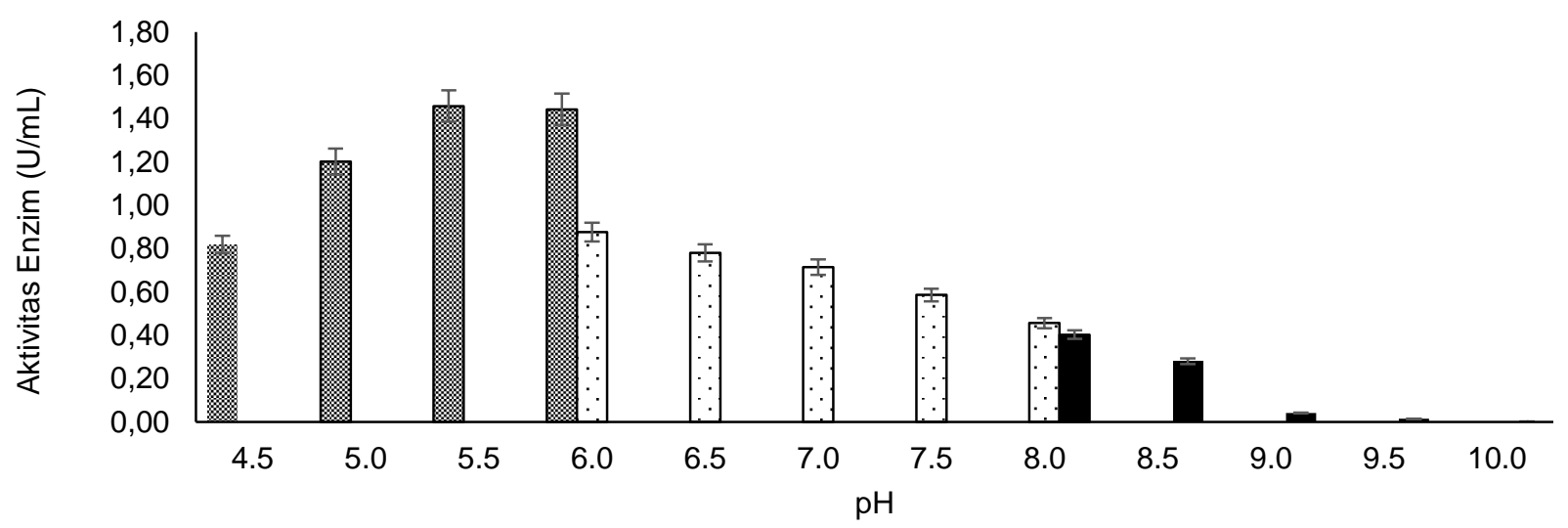

Gambar 3 Pengaruh pH terhadap aktivitas xilanase P26B4 diuji dengan menggunakan xilan beechwood 0,5\% pada suhu ruang.

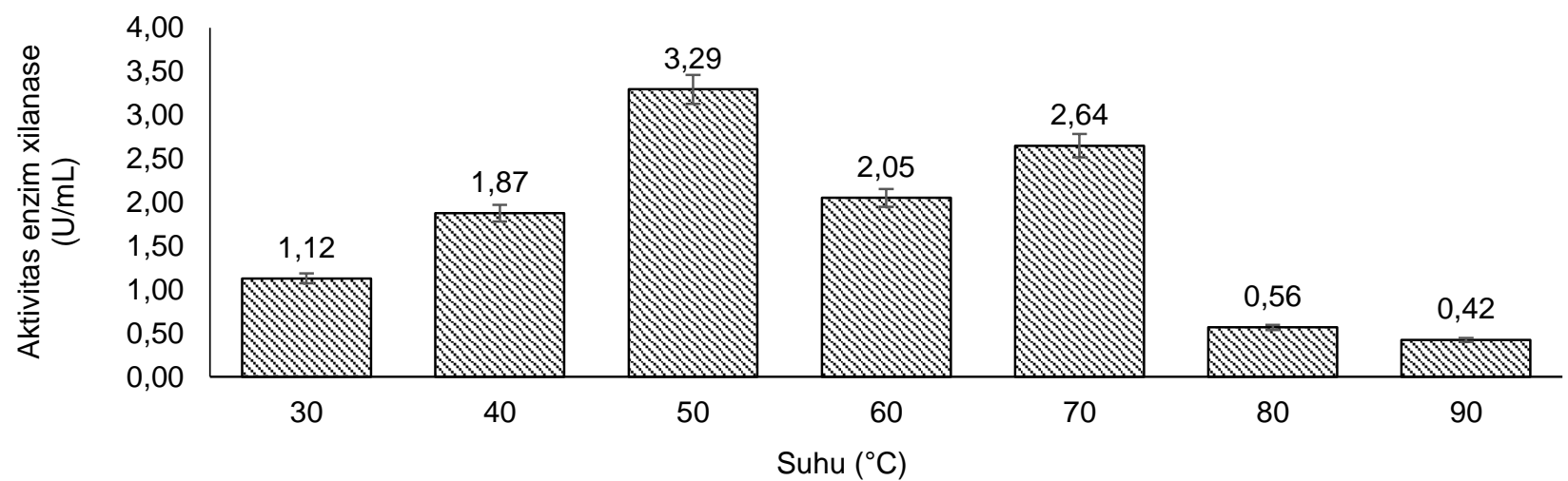

Gambar 4 Pengaruh suhu terhadap aktivitas xilanase P26B4 diuji dengan menggunakan xilan beechwood 0,5\%, bufer sitrat $\mathrm{pH} 5,5$.

1,4-xilanase dan $\beta$-D-xilosidase, selain itu keberadaan isoenzim endoxilanase dapat menyebabkan kemunculan puncak aktivitas lebih dari satu (Qing et al. 2013). Pada penelitian El-Dein et al. (2014) produksi enzim xilanase dari Streptomyces sp. K37 memiliki kondisi optimum yang sama pada penelitian ini yaitu pada suhu $50^{\circ} \mathrm{C}$. Berbeda dengan Chapla et al. (2012) menunjukkan bahwa enzim xilanase memiliki aktivitas rendah pada suhu $50^{\circ} \mathrm{C}$. Enzim xilanase Streptomyces P26B4 ini mampu menjadi biokatalis termotoleransi untuk aplikasi bioteknologi dan produksi enzim yang berasal dari mikroorganisme akan membantu mengurangi biaya produksi enzim. Enzim xilanase ini ketika dipanaskan pada suhu $80^{\circ} \mathrm{C}$ dan $90^{\circ} \mathrm{C}$ masingmasing memiliki aktivitas yang rendah sebesar 0,56 $\mathrm{U} / \mathrm{mL}$ dan $0,42 \mathrm{U} / \mathrm{mL}$. Hal ini terjadi karena kerusakan enzim menyebabkan fungsi dan aktivitas dari enzim tersebut berkurang. Kondisi suhu yang terlalu tinggi dapat menyebabkan protein enzim terdenaturasi yang berakibat pada hilangnya aktivitas enzim. Roy et al. (2013) menyatakan bahwa enzim xilanase yang memiliki stabilitas pada rentang $\mathrm{pH}$ 5-9 dan kisaran suhu $30-60^{\circ} \mathrm{C}$; karena itu memiliki potensi besar untuk digunakan dalam aplikasi biofuel, pakan ternak dan industri makanan.

Stabilitas enzim (Gambar 5) pada penyimpanan di suhu $28^{\circ} \mathrm{C}$ dan $10^{\circ} \mathrm{C}$ jam ke-0 hingga jam ke-96 memiliki kestabilan yang cukup baik karena memiliki aktivitas di atas $50 \%$ yaitu sebesar $59,36 \%$ pada suhu $28^{\circ} \mathrm{C}$ dan $67,14 \%$ pada suhu $10^{\circ} \mathrm{C}$. Xilanase dari Streptomyces sp. BO 3.2 stabil pada suhu $4^{\circ} \mathrm{C}$ dan $30^{\circ} \mathrm{C}$ masing-masing memiliki aktivitas 93\% dan 96\% tetapi tidak stabil pada suhu $60^{\circ} \mathrm{C}$ (Kholis et al. 2015). Hasil penelitian ini menunjukkan enzim xilanase ini stabil dan memiliki potensi keuntungan yaitu dapat memungkinkan waktu hidrolisis lebih lama dan jumlah enzim yang dibutuhkan lebih sedikit. Stabilitas enzim dapat dijadikan sebagai acuan dalam menentukan kondisi lingkungan penyimpanan enzim yang sesuai.

\section{Produksi XOS Melalui Hidrolisis Enzimatik}

Produk dari hidrolisis xilan secara enzimatik oleh xilanase dapat diidentifikasi berdasarkan peningkatan gula pereduksi dan penurunan derajat polimerasi (Meryandini et al. 2008). Proses hidrolisis menyebabkan terjadinya penurunan nilai DP. Terlihat bahwa nilai DP xilan tongkol jagung konsentrasi 3\%, 6\% xilan tongkol jagung dan $6 \%$ xilan beechwood pada jam ke0 nyata lebih tinggi dibandingkan pada jam ke- 6,12 , dan $24(p<0,05)($ Tabel 1).

Nilai DP xilan beechwood dan xilan tongkol jagung pada jam ke-0 berkisar 8-9, pada jam ke-6 hingga jam ke-24 menghasikan nilai DP 2-5. Penelitian Salupi et al. (2015) hidrolisis xilan tongkol jagung konsentrasi 
$1 \%$ menggunakan enzim Streptomyces violascens BF3.10 dengan nilai DP berkisar 2-5 pada jam ke3-24. Selanjutnya Kholis et al. (2015) substrat xilan konsentrasi $2 \%$ dihidrolisis oleh enzim Streptomyces sp. BO3.2 juga menghasilkan nilai DP 2-5 pada jam ke 1-12. Namun pada penelitian ini menunjukkan bahwa adanya peningkatan konsentrasi substrat yaitu $3 \%$ dan $6 \%$ masih dapat didegradasi oleh enzim xilanase. Peningkatan konsentrasi substrat masih dapat dihidrolisis oleh enzim disebabkan masih aktifnya enzim dalam menghidrolisis substrat dan didukung oleh hasil analisis stabilitas enzim, yaitu pada jam ke24 aktivitas enzim sebesar $82,5 \%$. Peningkatan nilai gula pereduksi yang dihasilkan berkorelasi positif terhadap peningkatan konsentrasi substrat. Semakin tinggi konsentrasi substrat dan lama waktu hidrolisis yang digunakan maka akan semakin banyak jumlah polimer substrat xilan yang dihidrolisis oleh enzim sehingga kadar gula pereduksi yang diukur semakin meningkat. Dari hasil tersebut diatas dapat menjadi keuntungan dalam proses degradasi substrat xilan dengan konsentrasi tinggi sehingga pemanfaatan produk samping pertanian semakin maksimal.
Hasil hidrolisis xilan tongkol jagung secara kualitatif diamati melalui KLT. Gambar 6 menunjukkan terdapat pita dari produk hidrolisis yang sejajar dengan standar xilosa, glukosa, manosa dan pita yang lain berada dibawah spot standar. Pita di bawah spot standar diduga merupakan senyawa xilooligosakarida yang masih memiliki rantai samping atau merupakan jenis xilooligosakarida lain dengan jumlah unit monomer yang berbeda seperti xilobiosa (X2), xilotriosa (X3), xilotetrosa (X4) atau jenis oligosakarida lain (Kumar \& Satyanarayana 2011). Perlakuan konsentrasi substrat menunjukkan adanya perbedaan pita yang dihasilkan pada masing-masing waktu hidrolisis. Xilan beechwood pada jam ke-0 dan jam ke- 6 menunjukkan belum terbentuk pita dengan keterpisahan yang baik, hasil hidrolisis tersebut diduga masih berupa xilooligosakarida rantai panjang, pada jam ke-12 dan jam ke-24 pita yang dihasilkan tampak jelas dengan keterpisahan yang baik. Sementara subtrat xilan tongkol jagung pada konsentrasi $6 \%$ dan 3\% menujukkan pita yang terbentuk sangat tipis pada jam ke-0, pada jam ke- 6, 12 dan 24 pita yang dihasilkan semakin jelas dan tebal seiring dengan bertambahnya waktu inkubasi namun tidak menunjukkan pita dengan

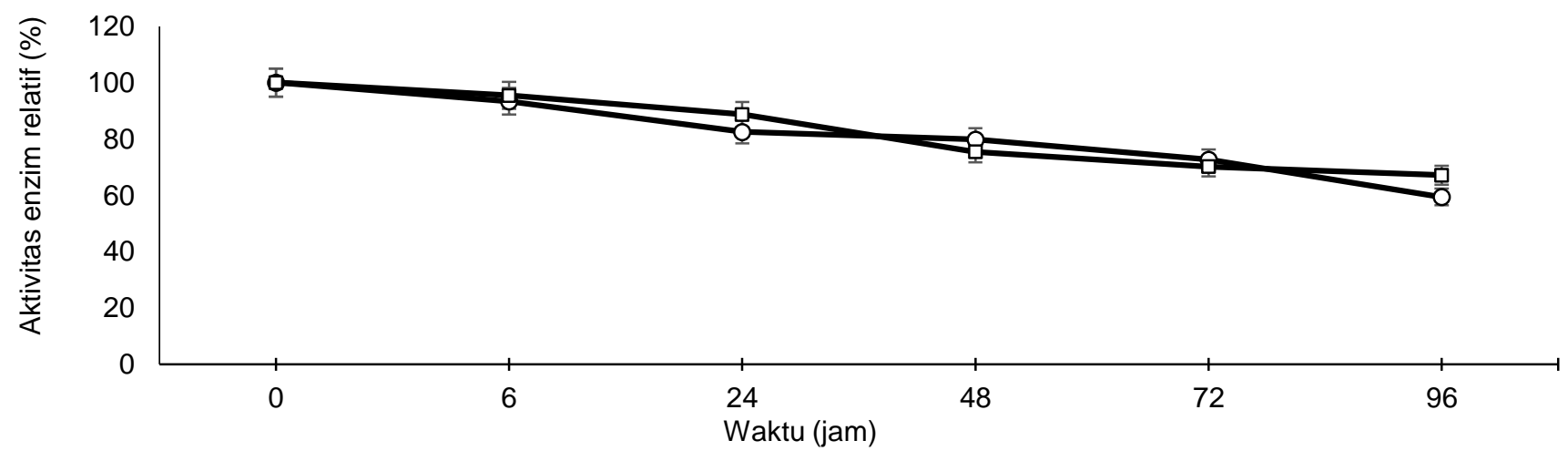

Gambar 5 Stabilitas enzim P26B4 pada suhu $10^{\circ} \mathrm{C}(-\circ-)$ dan $28^{\circ} \mathrm{C}(-\square-)$

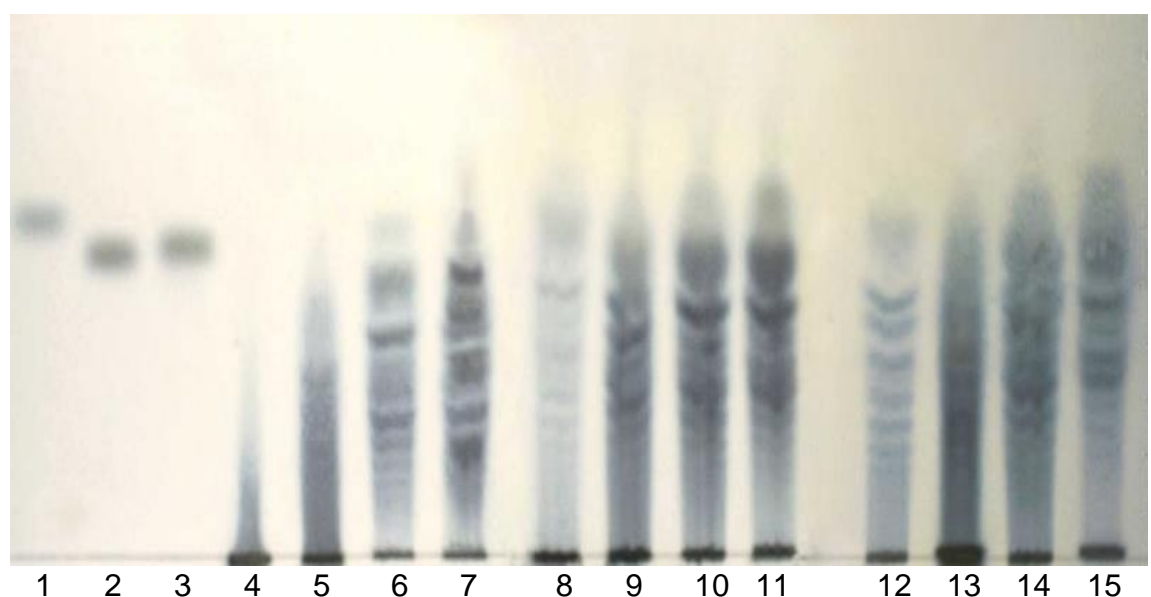

Gambar 6 Kromatografi lapis tipis pada produk hidrolisis xilan tongkol jagung dengan enzim xilanase isolat P26B4. 1= standar xilosa; 2= standar glukosa; 3= Standar manosa; 4=Xilan beechwood 6\% jam ke-0; 5= Xilan beechwood $6 \%$ jam ke-6; $6=$ Xilan beechwood $6 \%$ jam ke-12; $7=$ Xilan beechwood $6 \%$ jam ke-24; $8=$ Xilan tongkol jagung $6 \%$ jam ke-0; $9=$ Xilan tongkol jagung $6 \%$ jam ke-6; $10=$ Xilan tongkol jagung $6 \%$ jam ke-12; $11=$ Xilan tongkol jagung $6 \%$ jam ke-24; $12=$ Xilan tongkol jagung $3 \%$ jam ke- $0 ; 13=$ Xilan tongkol jagung $3 \%$ jam ke-6; 14=Xilan tonakol iaquna 3\% iam ke-12; 15= Xilan tonakol iaquna 3\% iam ke-24. 
keterpisahan yang baik jika dibandingkan dengan xilan beechwood. Hal ini disebabkan karena xilan beechwood memiliki kandungan xilan yang lebih seragam dibandingkan dengan xilan tongkol jagung karena xilan tongkol jagung tidak melalui proses pemurnian dalam ekstraksinya. Pita yang paling tebal ditunjukkan pada konsentrasi substrat $6 \%$ disbandingkan dengan konsentrasi 3\%. Hal tersebut menunjukkan bahwa semakin tinggi konsentrasi substrat maka semakin banyak produk hidrolisis yang dihasilkan sehingga pita yang terbentuk semakin tebal.

Konsentrasi substrat dan waktu berperan penting dalam hidrolisis enzimatik, ketika waktu inkubasi meningkat terjadi peningkatan produksi XOS dengan panjang rantai yang lebih rendah (xilobiosa dan xilotriosa) (Chapla et al. 2012; Samanta et al. 2015b). Proses degradasi tersebut disebabkan adanya aktivitas enzimatik di antaranya yaitu $1,4-\beta$-endoxilanase (EC.3.2.1.8) yang memotong ikatan $\beta-1,4$-glikosidik secara acak, dan $\beta$-1,4-eksoxilosidase (EC.3.2.1.37) memotong dua atau empat monomer bebas xilan pada ujung ikatan $\beta$-1,4-glikosidik (Kumar \& Satyanarayana 2015).

\section{Pemurnian Xilooligosakarida Menggunakan Khamir}

Ketika xilan dihidrolisis, maka akan terbentuk XOS dan monosakaridanya (xilosa). Untuk mendapatkan XOS dengan tingkat kemurnian yang lebih tinggi maka dilakukan penghilangan senyawa xilosa melalui penambahan khamir IP4. Telah dilaporkan sebelum-

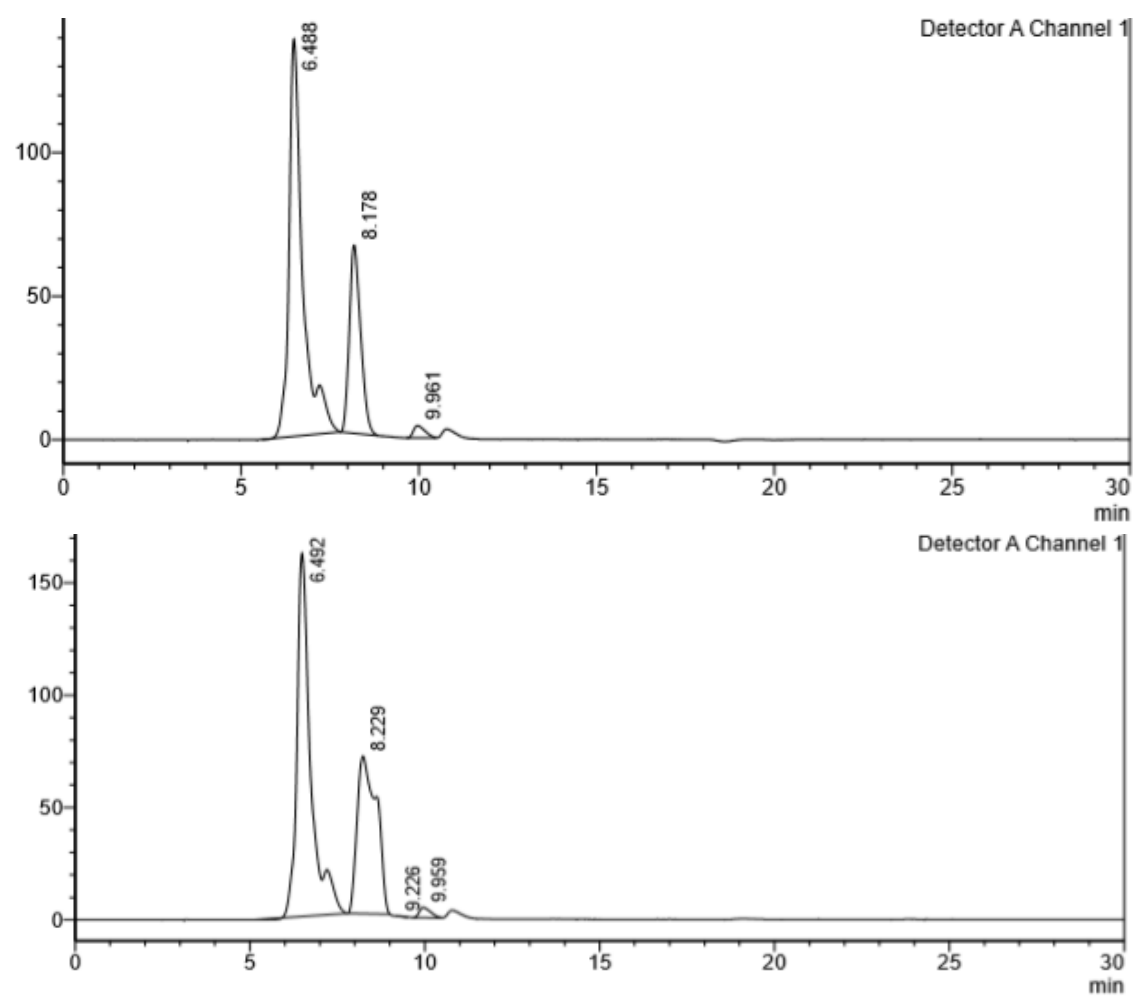

Gambar 7 Kromatogram HPLC sebelum penambahan khamir (a) dan setelah penambahan khamir (b) pada xilan tongkol jagung konsentrasi $6 \%$ pada jam ke- 24 . nya oleh Inderiani (2017) bahwa khamir IP4 ini merupakan salah satu khamir yang mampu menggunakan xilosa dengan baik, sehingga pada penelitian ini khamir IP4 digunakan agen untuk proses pemurnian. Penggunaan khamir menjadi salah satu metode yang juga telah digunakan untuk menghilangkan kandungan xilosa oleh Sangwan et al. (2014).

Hasil memperlihatkan kemampuan khamir untuk mengkonsumsi xilosa. Hal ini dibuktikan dari hasil analisis kromatogram HPLC (Gambar 7). Terlihat bahwa komponen xilosa sebelum penambahan khamir $(1,86 \%)$ mengalami penurunan setelah 8 jam inkubasi $(1,41 \%)$. Kromatogram juga memperlihatkan terbentuknya XOS dengan bobot molekul yang lebih tinggi dari xilosa (waktu retensi kurang dari 9,959-9,961 menit), sebagaimana dilaporkan juga oleh Mafei et al. (2019) yang mengidentifikasi xilopentosa dan xilotetraosa (X5 dan X4) dengan waktu retensi 7,2 menit, xilotriosa $(X 3)$ memiliki waktu retensi 8.2 menit dan xilobiosa (X2) memiliki waktu retensi 9,2 menit.

Komposisi produk setelah pemurnian sebanyak $61,10 \% \%$ merupakan X4-X5 (xilopentosa dan xilotetraosa), dan 37,45\% merupakan X2-X3 (xilobiosa dan xilotriosa) (Gambar 7b). Selain itu terdeteksi adanya glukosa setelah penambahan khamir sebesar $0,02 \%$. Komponen glukosa merupakan sumber karbon pada media YPG yang digunakan sebagai media inokulum. Namun Suarez-mendez et al. (2016) menyatakan bahwa adanya glukosa setelah penambahan khamir dapat berasal dari metabolisme karbohidrat oleh sel khamir. 


\section{KESIMPULAN}

Xilan dari tongkol jagung dapat dimanfaatkan untuk produksi enzim xilanase dari Streptomyces P26B4 dan produksi xilooligosakarida (XOS) oleh xilanase tersebut. Hasil hidrolisis tersebut menunjukkan terdapat produk XOS dan xilosa. Penambahan khamir IP4 dapat memurnikan XOS dengan menurunkan komponen xilosa dari $1,86 \%$ menjadi $1,41 \%$.

\section{UCAPAN TERIMA KASIH}

Kami mengucapkan terima kasih, sebagian hasil penelitian diperoleh dari dana ABS Fund dari grup B02CRC990 tahun 2018 atas nama Anja Meryandini.

\section{DAFTAR PUSTAKA}

Bhosale HJ, Sukalkar SR, Zaker S, Kadam TA. 2011. Production of xylanase by Streptomyces rameus grown on agricultural wastes. Biotechnol Bioinforma Bioeng. 1(4): 505-512.

Chapla D, Pandit P, Shah A. 2012. Production of xylooligosaccharides from corncob xylan by fungal xylanase and their utilization by probiotics. Bioresour Technol. 115: 215-221. doi: 10.1016/j.biortech.2011.10.083.

Collins T, Gerday C, Feller G. 2005. Xylanases, xylanase families and extremophilic xylanases. FEMS Microbiol Rev. 29: 3-23. doi: 10.1016/j.femsre.2004.06.005.

Dilip CV, S MS, Chavan DV. 2013. A review on Actinomycetes and their biotechnological application. Int J Pharm Sci Res. 4:1730.

Dubois M, Gilles KA, Hamilton JK, Rebers PA, Smith F. 1956. Colorimetric method for determination of sugars and related substances. Anal Chem. 28: 350-356. doi: 10.1021/ac60111a017.

EI-Dein NMM, Shereif AEA, Mansour FA, Abou-Dobara MI, Ball AS. 2014. Optimization of xylanase and peroxidase production from Streptomyces sp. K37. J Bio Sci Biotech. 3: 29-42.

Inayah MN, Ambarsari L, Meryandini A. 2016. Karakterisasi xilanase dari bakteri xilanolitik XJ20 asal tanah hutan taman nasional bukit duabelas Jambi Indonesia. J Sumberd Hayati. 2: 25-30.

Inderiani K. 2017. Seleksi dan identifikasi khamir asal fermentasi kakao di Sukabumi. [Skripsi]. Bogor (ID): Institut Pertanian Bogor.

Kementrian Pertanian 2019. Data Produksi Jagung 2019

Kumar V, Satyanarayana T. 2011. Applicability of thermo-alkali-stable and cellulase-free xylanase from a novel thermo-halo-alkaliphilic Bacillus halodurans in producing xylooligosaccharides. Biotechnol Lett. 33: 2279-2285. doi: 10.1007/s10529-011-0698-1.

Kumar V, Satyanarayana T. 2015. Generation of xylooligosaccharides from microwave irradiated agroresidues using recombinant thermo-alkalistable endoxylanase of the polyextremophilic bacterium Bacillus halodurans expressed in Pichia pastoris. Bioresour Technol. 179: 382-389. doi: 10.1016/j.biortech.2014.12.049.

Kholis MN, Yopi, Meryandini A. 2015. Xylooligosaccharide production from tobacco stalk xylan using xylanase. Makara J Sci. 19(2): 49-54. doi:10.7454/mss.v19i2.4738.

Knob A, Beitel SM, Fortkamp D, Terrasan CRF, Almeida AF De. 2013. Production, purification, and characterization of a major Penicillium glabrum xylanase using brewer's spent grain as substrate. Biomed Res Int. doi:10.1155/2013/728735.

Mano MCR, Neri-Numa IA, da Silva JB, Paulino BN, Pessoa MG, Pastore GM. 2018. Oligosaccharide biotechnology: an approach of prebiotic revolution on the industry. Appl Microbiol Biotechnol. 102: 1737. doi: 10.1007/s00253-017-8564-2.

Mafei TDT, Neto FSPP, Peixoto G, de Baptista Neto Á, Monti R, Masarin F. 2019. Extraction and characterization of hemicellulose from eucalyptus by-product: assessment of enzymatic hydrolysis to produce xylooligosaccharides. 190 (1): 197-217. Appl Biochem Biotechnol. doi: 10.1007/s12010019-03076-0.

Miller GL. 1959. Use of Dinitrosalicylic acid reagent for determination of reducing sugar. Anal Chem. 31: 426-428. doi: 10.1021/ac60147a030.

Meryandini A, Sunarti TC, Naomi A, Mutia F. 2008. Using Streptomyces xylanase to produce xylooligosacharide from corncob. Biotropia. 15 (2): 119-128. doi:10.11598/btb.2008.15.2.71.

Moniz P, Pereira H, Duarte LC, Carvalheiro F. 2014. Hydrothermal production and gel filtration purification of xylo-oligosaccharides from rice straw. Ind Crops Prod. 62: 460-465. doi: 10.1016/j.indcrop.2014.09.020.

Parajo JC. 2013. Fractionation of extracted hemicellulosic saccharides from Pinus pinaster wood by multistep membrane processing. 428:281289. doi: 10.1016/j.memsci.2012.10.021.

Pointner M, Kuttner P, Obrlik T, Jäger A, Kahr H. 2014. Composition of corncobs as a substrate for fermentation of biofuels. Agron Res. 12: 391-396.

Prakash D, Nawani N, Prakash M, Bodas M, Mandal A, Khetmalas M, Kapadnis B. 2013. Actinomycetes: A repertory of green catalysts with a potential revenue resource. Biomed Res Int. doi: 


\subsection{5/2013/264020.}

Putri E, Rukayadi Y, Sunarti TC, Meryandini A. 2019. Cellulolytic and xylanolytic Actinomycetes selection to degrade Lignocellulosic biomass of Robusta coffee pulp (Coffea canephora). IOP Conf Ser Earth Environ Sci. 299012014. doi:10.1088/17551315/299/1/012014.

Qing Q, Li H, Kumar R, Wyman CE. 2013. Xylooligosaccharides Production, quantification, and characterization in context of lignocellulosic biomass pretreatment, in: aqueous pretreatment of plant biomass for biological chemical conversion to fuels and chemicals. Aqueous Pretreat Plant Biomass Biol Chem Convers to Fuels Chem. 391415

Qiu Z, Shi P, Luo H, Bai Y, Yuan T, Yang P, Liu S, Yao B. 2010. A xylanase with broad $\mathrm{pH}$ and temperature adaptability from Streptomyces megasporus DSM 41476, and its potential application in brewing industry. Enzyme Microb Technol. 46: 506-512. doi: 10.1016/j.enzmictec.2010.02.003.

Rastall RA, Gibson GR. 2015. Recent developments in prebiotics to selectively impact beneficial microbes and promote intestinal health. Curr Opin Biotechnol. 32: 42-46. doi: 10.1016/j.copbio.2014.11.002.

Roy S, Dutta T, Sarkar TS, Ghosh S. 2013. Novel xylanases from Simplicillium obclavatum MTCC 9604: Comparative analysis of production, purification and characterization of enzyme from submerged and solid state fermentation. Springerplus. 2: 1-10. doi: 10.1186/2193-1801-2382.

Salupi W, Yopi, Meryandini A. 2015. Xylanase activity of Streptomyces violascences BF 3.10 on xylan corncobs and its xylooligosaccharide production. Media Peternak. 38: 27-33. doi: 10.5398/medpet.2015.38.1.27.

Samanta AK, Jayapal N, Jayaram C, Roy S, Kolte AP, Senani S, Sridhar M. 2015a. Xylooligosaccharides as prebiotics from agricultural by-products: Production and applications. Bioact Carbohydrates Diet Fibre. 5: 62-71. doi: 10.1016/j.bcdf.2014.12.003.
Samanta AK, Jayapal N, Kolte AP, Senani S, Sridhar M, Dhali A, Suresh KP, Jayaram C, Prasad CS. $2015 \mathrm{~b}$. Process for enzymatic production of xylooligosaccharides from the xylan of corn cobs. $J$ Food Process Preserv. 39: 729-736. doi: $10.1111 /$ jpp. 12282.

Sangwan V, Tomar SK, Ali B, Singh RRB, Singh AK, Mandal S. 2014. Galactooligosaccharides purification using microbial fermentation and assessment of Its prebiotic Potential by in vitro method. Int J Curr Microbiol App Sci. 3: 573-585.

Singh RD, Banerjee J, Arora A. 2015. Prebiotic potential of oligosaccharides: A focus on xylan derived oligosaccharides. Bioact Carbohydrates Diet Fibre. 5: 19-30. doi: 10.1016/j.bcdf.2014.11.003.

Suarez-Mendez CA, Hanemaaijer $M$, ten Pierick $A$, Wolters JC, Heijnen JJ, Wahl SA. 2016. Interaction of storage carbohydrates and other cyclic fluxes with central metabolism: A quantitative approach by non-stationary 13C metabolic flux analysis. Metab Eng Commun. 3: 52-63. doi: 10.1016/j.meteno.2016.01.001.

Taherzadeh MJ, Karimi K. 2007. Process for etahanol from lignocellulosic materials: acid based hydrolysis process. Bioresources. 2(3): 474-499.

Ting ASY, Hermanto A, Peh KL. 2014. Indigenous Actinomycetes from empty fruit bunch compost of oil palm: Evaluation on enzymatic and antagonistic properties. Biocatal Agric Biotechnol. 3: 310-315. doi: 10.1016/j.bcab.2014.03.004.

Zhao LC, Wang Y, Lin JF, Guo LQ. 2012. Adsorption and kinetic behavior of recombinant multifunctional xylanase in hydrolysis of pineapple stem and bagasse and their hemicellulose for Xylooligosaccharide production. Bioresour Technol. 110: 343-348. doi: 10.1016/j.biortech.2012.01.076.

Zheng HC, Sun MZ, Meng LC, Pei HS, Zhang XQ, Yan Z, Zeng WH, Zhang JS, Hu JR, Lu FP, Sun JS. 2014. Purification and characterization of a thermostable xylanase from Paenibacillus sp. NF1 and its application in xylooligosaccharides production. J Microbiol Biotechnol. 24: 489-496. doi: 10.4014/jmb.1312.12072. 